\title{
Exploration of the Macro Ideas about the Construction of the College Study Guiding System in China Based on the Application of the Kernel of Western Academy System
}

\author{
Di Xuan \\ Changzhou University, Changzhou 213164, China \\ E-mail: derekxuan@126.com
}

Received: April 20, 2011 Accepted: May 11, $2011 \quad$ doi:10.5539/res.v3n1p110

\begin{abstract}
Because of many superposition parts between the western academy system (in Britain and America, the academy is often called as the accommodation college system. By using the ancient academy system of China for reference, Hong Kong scholar translated the accommodation college as the academy. To distinguish with the current administration system of school and department based on subject in China mainland, the name of "academy" is adopted in this article) and the study guiding practice in China, it is possible to introduce the essences of the academy system to fulfill the theoretical research and practice of the study guiding in Chinese colleges. Based on the kernel of the academy system, the study guiding system of college includes the value system, the basic system, and the important system. To effectively implement the study guiding, the certain organization assumptions should joint with the practical frame.
\end{abstract}

Keywords: Study guiding, Academy system, General education, Tutorial system

\section{Possibility analysis of the application of the academy system in the construction of the college study guiding system}

In US and Europe with developed education, many famous universities implement the academy system and the school system simultaneously, such as the Oxford University, the Cambridge University of UK, the Yale University of US, and the Chinese University of Hong Kong also adopts such one education management mode. Academy and school have their own works and they have no subordinate relationship each other. The school and department mainly are responsible for students' education of base theory and professional knowledge and scientific research, and students' daily life, courses of general education, and non-formal education are implemented and administrated by the academy (Xu, 2003).

In Britain and America, the academy established by university has independent legal personality, and its own laboratory, library, chapel, speech hall, and other teaching equipment, and it not only provides students' board and lodging, but arranges their academic, religion, recreation, sports, and social activities. In Yale University, freshmen will be randomly distributed into 12 academies, and except for special situation, students will live in the academy for four years. In Oxford, once freshmen are enrolled, the academy will appoint one tutor who will meet the student at fixed period, listen the students' reading gains, or discuss certain one problem with the student, instruct the student to make his study plan, and culture the student's morality. The tutors are engaged in professors, which is one of important responsibilities for teachers, and the tutors generally live in the academy, teaching by their personal examples as well as verbal instruction, and influencing the students by unconscious way. The top leader of western academy is the president, who is responsible for finance, assets, and students' health, safety, and cultural life arrangement. In addition, there are dean of studies, administration secretary, tutor, and student administrator in the academy.

Though the academy systems in different developed countries are different, the core content of the western academy system contain following aspects. First, implement the "people-oriented education" concept, provide complete facility, graceful environment, independent and delicate life, study, and social space where students will generate strong sense of belonging, and build the special cultural atmosphere for the academy. Second, pay attention to the general education. The purpose of the general education in the academy system is to open extensive, non-professional, and non-material courses including basic knowledge, techniques, and attitude, with corresponding activities, and cultivate students' abilities such as effectively thinking (including logical reasoning, 
relationship understanding, and imagination), communication, judgment, identification and selection of various value views ( $\mathrm{Wu}, 2005)$. In addition, the academy system breaks the limitation of subject, and realizes the mutual integration of science, engineering, arts, and management. Third, it takes the non-formal education as the major education mode, including tutorship, academic forum, special plan, debate, visit, community service, academic party, and academic dinner party. Finally, implement the teaching of tutorial system. The tutorial system is the core of the academy system, which is a kind of teaching system that the tutor periodically instructs the student individually for his study, morality, and life. By the tutorship course once a week, the tutor can realize the individual education through the stages including "student reports his work- the tutor appraises the student's work- both tutor and student discuss the work together".

In recent years, "study guiding" has been the work content in some colleges, but it is still deficient to discuss the concept and the system construction. Just as its name implies, the study guiding means to lead students' learning, research, and study, and its position is before or after the teaching (generalized study guiding even runs through the teaching, and it is a kind of professional teaching method, this study guiding which belongs to general professional teaching is not included in this article), but its range far exceeds the study plan, so it is a new concept with strong generalization effect. As what mentioned before, in the universities in developed countries, except for students' education of base theory and professional knowledge and scientific research, the academy is the carrier that students live and accept the course of general education and the non-formal education, and when ensuring the quality of students' professional learning, the academy should provide other conditions to promote the development for students' other capacities and qualities, and stimulate students' potential as more as possible. Therefore, Because of many superposition parts between the western academy system and the study guiding practice in China, it is possible to introduce the essences of the academy system to fulfill the theoretical research and practice of the study guiding in Chinese colleges.

\section{Construction of Chinese study guiding system: Construction and integration based on the academy system}

\subsection{Value system of college study guiding}

In the western study education domain, the teaching method of university (the concept of "university" here is the concept relative to "academy", and mainly means the department of teaching and research in the university) is the instruction mode, but the teaching method of academy is tutorship mode, and university exists for passing on knowledge, and the function of academy is to develop the personal characters (M.G. Brock and M.C. Curthoys, 1997, P. 293). The characters here include students' capacity to independently solve professional problems and study professional knowledge, independently thinking habit and ability, clear analyzing, proofing, and expressing ability, the respect to the knowledge, and lofty studying quality. From the practice of the academy in the Chinese University of Hong Kong, the general education is the important content for the academy education. It cannot be denied that the departments in the university also add the "character" education in the teaching courses including classroom teaching, lecture course, proseminar, selection, postgraduate instruction, theses checking, and examination, but the tutorial system which major form is the individual instruction based on the double-directional cooperation between student and teacher in the countries with developed education has been recognized as the optimal mode to cultivate "character", which is key that Oxford and Cambridge can attract and cultivate the top talents in the world.

The current education system of "academy system" in the mainland of China equals to the department instruction teaching in western "university". However, the instruction teaching could not realize the education target of promoting students' comprehensive development based on the "student development theory", and the education that colleges in China form students' character of study should be the value point of the construction and practice of the study guiding system. In this article, the value system of the college study guiding includes three layers. The first layer is the complementation of students' professional knowledge and comprehensive establishment of their general education structures. The second layer is to enhance students' ability of comprehensive learning. The ability of comprehensive learning includes the innovation ability, the independent thinking ability, the effective thinking ability (clear thinking, demonstration, logic reasoning, relationship understanding, and imagination), and the judgment ability, the ability of solving problem, the self-studying ability, the communication ability, and the expression ability. The third layer is to form students' study character. The study character means the willpower and durative of study, the lofty academic morality, sentiment, and value view. The value system of the study guiding will lead the construction of the study guiding theoretical system and the practice of the study guiding. 


\subsection{Basic system of college study guiding: realizing the general education of the study guiding value}

The general education was born in the popular stage of higher education in western developed countries (especially in USA), and it "is not only a kind of idea of university, but also a kind of talent cultivation mode. And its target is to cultivate complete person with far vision, knowledge and experience, gentle spirit, and beautiful sentiment, not the talent being good at only one narrow professional domain. In the mode of general education, students will form deep and strong professional base, and reasonable knowledge and capacity structure through a comprehensive study mode, and know and understand the modern society, and develop their comprehensive personality quality and wide knowledge vision (Chen, 2006)".

In the stage of higher education, the general education provides the instruction of basic human culture, social and scientific knowledge, the building of personality quality, the civilian consciousness, the cultivation of the sense of social responsibility, and the cultivation of some practical abilities which are not needed in the professional education to all students, and the final target of the general education is the comprehensive, sufficient, and free development of people.

The aim of study guiding is to cultivate students' ability of comprehensive study and good study character, and in the general education, such education value system can be realized. In the general education, students can form deep knowledge base and reasonable knowledge and capacity structure through a compressively study way. By realizing students' civilian responsibility, healthy personality, mutual care consciousness, and team cooperation ability, the general education can help to form good study character for students.

At present, the advanced general course education system in China is in the "Fudan Academy" of Fudan University, and its core course system includes six modules such as the literature and history and cultural inheritance, the philosophical wisdom and criticized thinking, the civilized dialogue and world vision, the science advancement and scientific spirit, the ecological environment and life care, the arts creation and appreciation of the beauty. In the Chinese University of Hong Kong, the general education is developed through many special plans. For example, the "special plans" in the United College mainly include "Elite Leader Training Plan", "Fellow Student Plan", "Budding Academic Communication Plan", "Good Book Reading Plan", "Outstanding Visit Talent Plan", "Visit Scholar Plan", and "Chinese Improvement Plan".

In a word, the basic content of the college study guiding is to develop students' general education based on the guided value system, which is realized depending on formal or non-formal general education courses or the special plans of general education with different topics.

\subsection{Important system of college study guiding: tutorial education}

Mohr, the tutor of the St. Johns College of Oxford University, pointed out that the successful reasons of the tutorial system of Oxford University lied in three aspects, i.e. paying attention to the individual, depending on teacher and students' cooperation, and the special attitude of treating knowledge (Will G. Moore, 1968, P. 24). So to speak, it is the kernel of the teaching concept of tutorial system. Generally speaking, the tutorial system includes three characters. First, it emphasizes the individual instruction to student, and with the popularization of higher education, the one-to-one tutorial teaching is not universal in western universities at present, and in most situations, a few students go to class together. Second, the tutorial teaching is based on the interaction between teacher and student. On the one hand, the tutor encourages students to play active role in the study and cultivate their ability in independent learning, thinking, criticism, and work. On the other hand, the tutor is critical instructor, and help student to select the research method and dig materials to analyze. Third, the core target of the tutorial teaching is to cultivate students' ability of exploring knowledge and thinking independently.

With the population of higher education in China, the tutorial system in the college study guiding cannot be strictly fixed in the individual instruction to student, which is the development tendency of the tutorial system in many advanced countries. The report of North Committee in 1997 showed that $17.3 \%$ of undergraduates' tutorial courses in the Oxford University were shared by four or more students (Ted Tapper and David Palfreyman, 2000, P. 103). In Harvard University, the work of tutor is often undertaken by professional and senior professors and scholars, and general professional teachers, even postgraduates. In China, the education form of tutorial system should be fixed in the group discussion or Seminar, and the task is mainly undertaken by the professional teachers in the department, or the outstanding talents in the society.

In Britain and USA, especially in Britain, the target of tutorial system is to promote students for thinking independently and teach them how to think, and the problems discussed between teacher and students and the 
books read by students are not only limited in the specialty, but in the guidance of students' study plan, and students' good study character and sentiment will unconsciously be formed in the contact with tutor. From the practice in China, the teaching content of tutorial system should include following aspects. First, instruct undergraduates' study and solve their study difficulties and confusions. Arrange and concretely instruct students to accomplish the theses, research reports, and surveys. The works and comment topics can be limited in the specialty, or involve multiple subjects or domains. The students instructed by same one tutor can discuss certain one topic with the tutor by the forms such as group discussion, debates, "brain storm", Seminar, and salon. These methods can reduce students' formal lesson time, and save sufficient time to actively study in the tutor's instruction, and make talents with outstanding academic ability show themselves. Second, help students to do the study plan and career plan (on the layer of study guiding, the career plan is the important supplement of career plan, and the measure and method to realize the value of study guiding). Most tutors are the famous expert scholars or young doctors in the domain, and their successful experiences in study and career should be studied, and their achievements should be adored imitated by students, which could unconsciously lead students to study correct value view. Third, instruct students' professional practice and other social practice. The practice is the extension of theoretical study. The enhancement of students' comprehensive study ability must be realized in the practical environment. These practices include relative academic activities, united activities between university and enterprise, scientific innovation, business creation, special plan, and other social activities aiming to realize the value of guided value.

\section{Construction of the implementary organization of college study guiding: joint between certain assumption and practical frame}

The western general education and the tutorial education are born, developed and performed in the academy and its system arrangement. When applying the kernel of western academy system in the construction of the study guiding system of China, the certain organization arrangement should be the establishment of the local academy system in China. However, the Colleges in China adopt the bureaucracy system to administrate themselves, and in the short time, it is not possible to realize that colleges completely reform the current administration system and the administration mode. If the study guiding is only accomplished by the current students administration system, the value of the study guiding in the article will not be realized.

Therefore, colleges in China should adopt the gradual improvement mode to push the study guiding system, i.e. integrate the system arrangement of study guiding into the current college administration system, and finally realize the study guiding mechanism in the academy system, and exert its values.

At present, for the organization, the study guiding of college should accomplished by the educational administration, the students administration, the Youth League Committee, and the departments together, and the power to administrate and implement the study guiding work should be divided in four aspects, with mutual cooperation and balance. As the important contents in the study guiding, the general education and the tutorial education should mainly be accomplished by the educational administration and departments. In the educational administration office, the office of general education should be established to make the core course system of general education, compile the teaching plan, outlines, and teaching materials, and concretely implement the teaching. In addition, the tutorial teaching should be administrated and pushed by the educational president and the office of educational administration in various departments. Because of the non-formal character of the study guiding form, the organization and coordination of all seminars, meetings, lectures, and special plans should be administrated by the Youth League Committee and the students administration. In addition, the Youth League Committee and the students administration should educate students in the correct direction of the social mainstream value based on the cooperation with the tutor. For the staffing, the professional teachers with title of associate professor or professor or doctor's degree in various subjects should be transferred to administrate the study guiding work, and link it with the teacher performance and largely enhance the relative proportion, which could strongly encourage other teachers to participate in the study guiding work. Second, various colleges should constitute concrete standards to classify the teachers for the scientific research type and the teaching type according to their own practice, and set up corresponding posts and performances. In this way, the deficiency of guided teachers can be solved, and related teachers can enhance their economic treatments and be recognized by the society through the study guiding work. Finally, in the concrete implementation of the study guiding education, to face the negative effect of the popularization of higher education, colleges should transfer the doctoral candidates in the college and the instructors with certain teaching and scientific research ability to undertake the assistant of tutor, and enrich the tutor group. 


\section{References}

Chen, Xiangming. (2006). An analysis of some concepts about general education. Journal of Higher Education, No. 3.

M.G. Brock \& M.C. Curthoys. (1997). The History of the University of Oxford (V6). Oxford: Clarendon Press. p. 293.

Ted Tapper \& David Palfreyman. (2000). Oxford and the Decline of the Collegiate Tradition. London: Woburn Press. p. 103.

Will G. Moore. (1968). The Tutorial System and its Future. New York: Pergaman Press, p. 24.

Wu, Lingen. (2005). The Enlightenment of General Education in American Universities towards Chinese Qualification-oriented Education. Journal of Anhui University of Technology (Social Sciences), No. 5.

Xu, Delong, Pan, Zhongwei, Liu, Yongqiang \& Shao, Bilin. (2003). Trying Out the Academy Subject System to Explore the New Mode of Quality Education. China Higher Education Research, No. 1. 